\title{
A Case Report on Management of unusually presenting Anorectal Giant Condyloma Acuminata
}

Dr. M.K. Maheshwari*, Dr. Siddhant Kumar, Dr. Vaibhav Kr Singh, Dr. Sandeep Kansal

Dept. of General Surgery, Subharti Medical College, Delhi Meerut Bypass Road, Meerut, UP - 250005, India

DOI: $10.36347 /$ sasjs.2020.v06i03.005

| Received: 28.02.2020 | Accepted: 06.03.2020 | Published: 13.03.2020

*Corresponding author: M.K. Maheshwari

\section{Abstract}

Condyloma acuminata, or anogenital warts, caused by human papillomavirus are a common sexually transmitted disease. In rare cases, the disease could progress to an extensive neoplasm called Buschke-Löwenstein tumour (BLT), also known as giant condyloma acuminatum. BLT differs from normal condyloma acuminata by presenting with locally invasive growth, lack of spontaneous resolution, and tendency for recurrence after treatment and potential for malignant squamous cell carcinoma. Risk factors include anoreceptive intercourse, HIV and immunosuppression. We present a case of perianal BLT and discuss about the nature and treatment of this disease. Wide perineal excision with negative margins is the best surgical choice if the anal canal is not involved. The radical pelvic surgery is indicated only in patients with proved visceral invasion. Excision is mandatory even in very small condylomas to prevent BLT later.

Keywords: Unusually presenting Condyloma Acuminata.

Copyright @ 2020: This is an open-access article distributed under the terms of the Creative Commons Attribution license which permits unrestricted use, distribution, and reproduction in any medium for non-commercial use (NonCommercial, or CC-BY-NC) provided the original author and source are credited.

\section{INTRODUCTION}

Buschke-Löwenstein tumour (BLT), or giant condyloma acuminata, was initially described in 1925 . Incidences of BLT have been reported in mostly anogenital regions $[1,3]$.

BLT is a slow-growing, cauliflower-like, locally destructive tumour and has propensity for secondary infections, foul odour and fistulations [4]. GCA is a rare lesion tending to present in the fifth decade with a 2.7: 1 male: female ratio.

Risk factors include HPV $(6,11)$ anoreceptive intercourse, HIV and immunosuppression. It has a lowgrade histopathological appearance and rare metastasis, BLT is generally classified as a verrucous carcinoma, a well-differentiated regional variant of squamous cell carcinoma [5]. It is characterized by aggressive down growth into underlying dermal structures.

Mostly, patients present with bleeding, lymph node enlargement, peri anal fistula and discharge. The loco-regional extension must be carefully ascertained to establish the management.
BLT treatment is controversial, the majority of authors agree that surgery is the treatment of choice and is efficient in the early stages of the disease. Wide local excision is to be done and lymph node dissection is indicated only in cases of suspected malignancy.

BLT is associated with high local recurrence after excision in about 50-60\% and the need of pre- and postoperative use of radiation and chemotherapy has been suggested. Post op surveillance is mandatory because of high recurrence rates.

\section{CASE REPORT}

28 year old male came with chief complaints of peri rectal mass, slowly growing for the past six years. The mass was insidious in onset and gradually progressing from initial size of approx. $3 \mathrm{~cm} \mathrm{x} 4 \mathrm{~cm}$ (approx.) to current size of $14 \mathrm{~cm} \mathrm{x} 13 \mathrm{~cm}$.

On examination, patient had a cauliflower like tumour in the peri rectal region extending from anal verge to $\mathrm{S} 4$ vertebra. Biopsy taken from the mass suggested Condyloma Acuminata.

MRI Pelvis s/o large heterogenous exophytic growth in perianal region measuring $15 \times 14 \times 9 \mathrm{~cm}$ with multiple branching linear tracts seen within the lesion 
extending supero-anteriorly external to external sphincter without obvious internal communication with the anus. Loss of fat plane with anal canal noted and anal canal is displaced towards the left side.

Routine blood investigations were done and patient was found to be severely anaemic ( $\mathrm{Hb}$ : $4.8 \mathrm{gm} / \mathrm{dl}$ ) and GBP suggestive of microcyctic hypochromic anaemia. 4 units PRBC were transfused and the patient was taken up for surgery.
Wide local excision of mass was done leaving the anal mucosa and the anal verge intact. Gluteal V-Y flap advancement was performed to cover the defect. Sigmoid colon loop was mobilised and colostomy done. Complete excision was achieved. Post-operative period was uneventful.

HPE was suggestive of: Wide excision of gluteal mass shows features of condyloma acuminate. Three months following surgery no recurrence was seen.

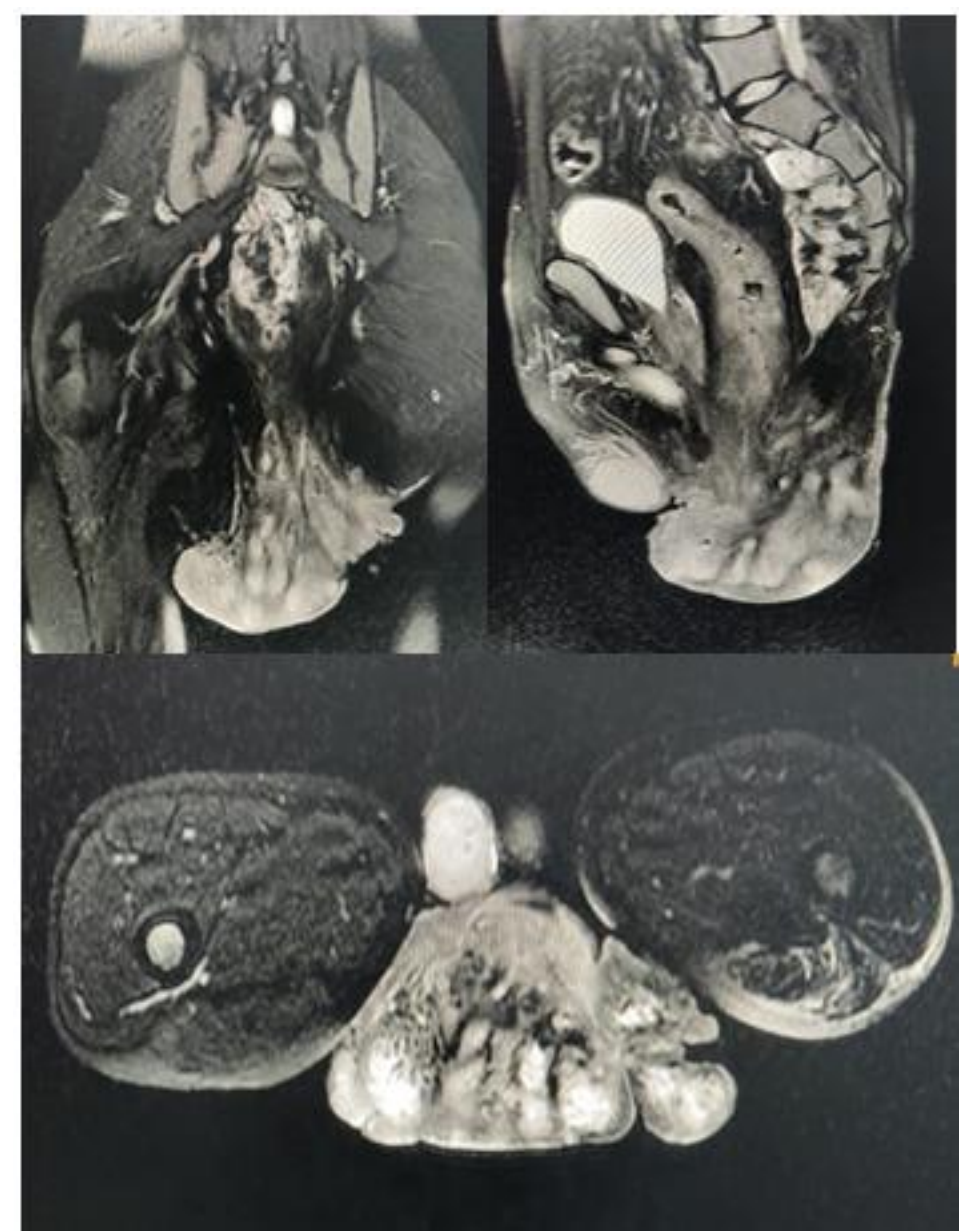

Fig-1(a), 1(b), 1(c): MRI Pelvis showing large $(12 \times 12 \times 9 \mathrm{~cm})$ heterogeneously exophytic mass lesion in perianal region

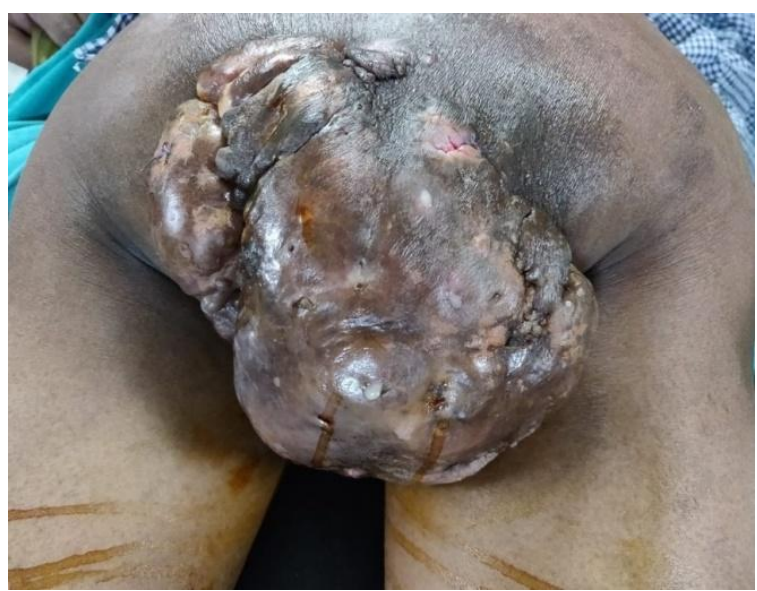

Fig-2: Clinical Presentation of Peri anal mass

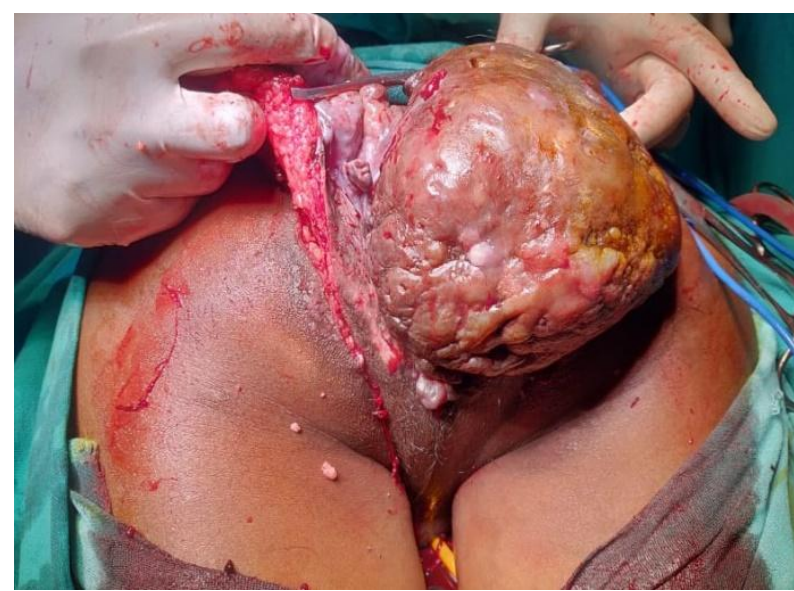

Fig-3: Intra-op picture of mass resection 


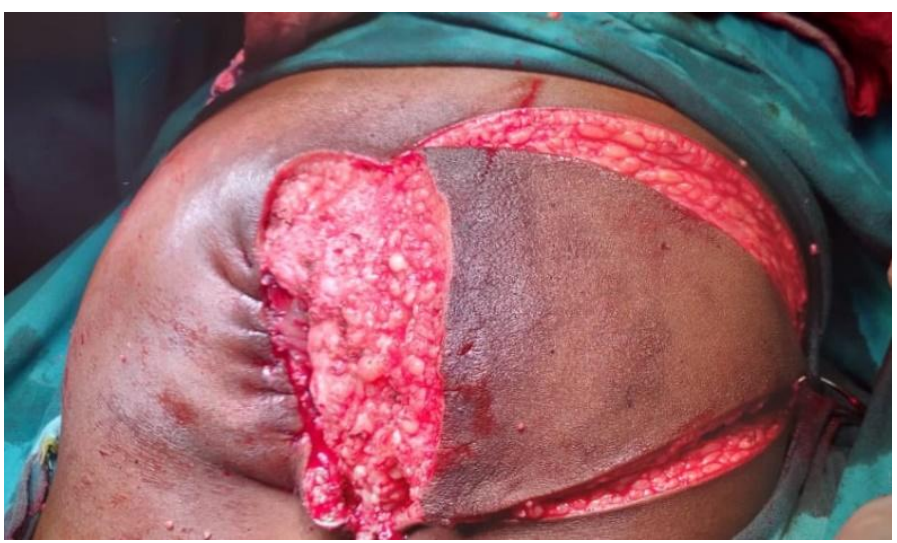

Fig-4: V-Y Gluteal flap advancement

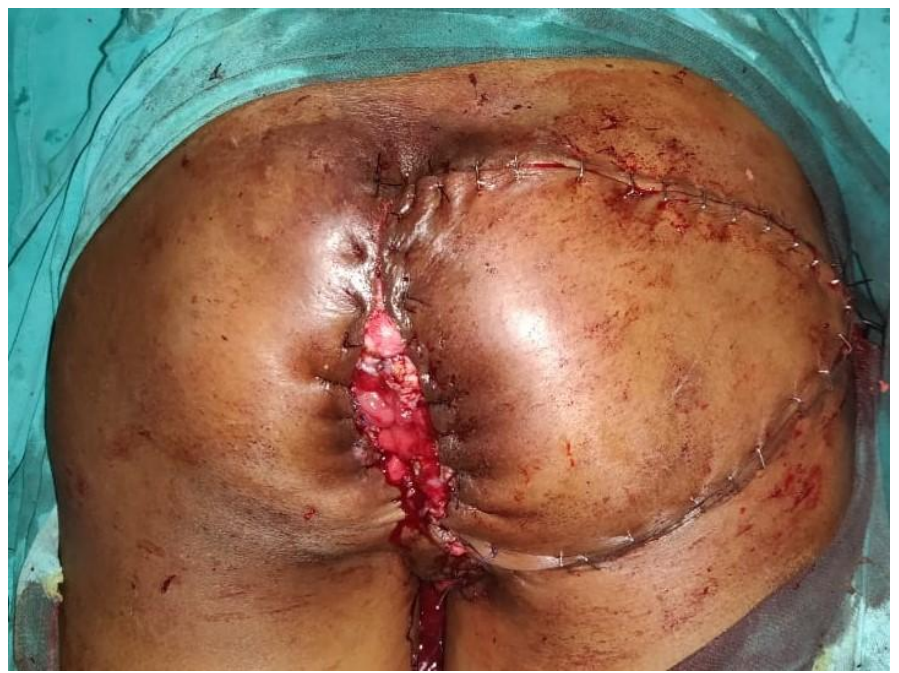

Fig-5: Post resection and flap coverage

\section{DISCUSSION}

Buscke-Lowenstein tumour is a rare entity, with an incidence of $0.1 \%$ in the general population [17-19]. Predominantly affects men, with few reports in women, being more common during pregnancy [17-22]. Presents rates of up to $56 \%$ of malignant transformation to squamous cell carcinoma, $66 \%$ recurrence and $20 \%$ mortality, with fatal cases only in recurrences [17-19, 23 , 24]. This disease has been considered an intermediate step between squamous carcinoma and condyloma acuminata or a benign entity in itself with malignant behaviour [18, 19, 23-25]. There are little known clinical characteristics and imaging, and there is no agreement on handling/management. Risk factors described are HPV subtype infection [6, 11, 16, 18], immunosuppression (HIV infection, use of corticosteroids, immunomodulators, diabetes mellitus) sexual promiscuity and co-existence of condylomas [18, 19, 22]. The most frequent locations in males are the penis (81-94\%) and in females the vulva (90\%), secondly in both sexes is the perineum [19, 24, 26]. Lymphadenopathy associated with this lesion are mostly reactive to the lesion or super infection, they rarely correspond to metastasis [19, 24, 26, 27].

Clinically these lesions often present with similar findings, and can be distinguished by histological examination $[30,31]$. BLT resembles condyloma acuminatum histologically with its benign appearance and negligible cellular atypia, but also has characteristics of thick stratum corneum, marked papillary proliferation, deep local invasion and displacement of surrounding tissues. These features, seen also in verrucous carcinomas, led several authors not to recognize a distinction between verrucous carcinoma and Buschke Löwenstein tumour [28]. However, GCA does not present histological evidence of malignancy, such as infiltration of basement membrane, lymphatic invasion, angioinvasion or distant metastases [32]. Despite this, GCA can coexist with verrucous carcinoma or squamous cell carcinoma in up to $50 \%$ of patients $[29,33]$.

Due to its rarity and lack of controlled studies, the optimal management for BLT has not been defined. However, wide local excision with tumour-free margins remains the treatment of choice along with several other therapeutic strategies, including topical agents (podophillin, 5-fluorouracil, bleomycin, interferon and imiquimod) or systemic therapy with chemoradiation [13]. Since the tumour has minimal potential for distant metastasis, local control of the disease usually leads to improved prognosis [14]. 
Although surgical excision remains the mainstay treatment, definitive chemoradiation could possibly be used to treat certain cases of recurrence or extensive pelvic invasion, and potentially decrease local recurrence rates [13].

While vaccination is an effective method for preventing anogenital warts, early and adequate treatment of condyloma acuminata could prevent its potential growth into an extensive verrucous tumour. Early detection of the disease and close vigilance and follow-up could have led to a better outcome in our patient.

\section{CONCLUSION}

The treatment of choice for Buschke Löwenstein tumour is debatable because of the rarity of the disease. In our opinion, wide local excision with tumour free margins and same sitting reconstruction of skin defect appears to be the best choice.

\section{REFERENCES}

1. Buschke A, Löwenstein L; Über karzinomähnliche Condylomata acuminata des Penis. Klin Wochenschr, 1925; 4: 1726-1728.

2. Dawson DF, Duckworth SK, Bernhardt H, young JM; Giant condyloma and verrucous carcinoma of the genital area. Arch Pathol, 1965; 79: 225-231.

3. Ahsaini M, Tahiri Y, Tazi MF, Elammari J, Mellas S, Khallouk A, El Fassi MJ, Farih MH, Elfatmi H, Amarti A, Stuurman-Wieringa RE. Verrucous carcinoma arising in an extended giant condyloma acuminatum (Buschke-Löwenstein tumor): a case report and review of the literature. Journal of medical case reports. 2013 Dec 1;7(1):273.

4. Grassegger A, Höpfl R, Hussl H, Wicke K, Fritsch P. Buschke-Loewenstein tumour infiltrating pelvic organs. British Journal of Dermatology. 1994 Feb;130(2):221-5.

5. Sandhu R, Min Z, Bhanot N. A gigantic anogenital lesion: Buschke-Lowenstein tumor. Case reports in dermatological medicine. 2014;2014.

6. Parise P, Sarzo G, Finco C, Marino F, Savastano S, Merigliano S. Giant condyloma acuminatum of the anorectum (Buschke-Lowenstein tumour): a case report of conservative surgery. Chirurgia italiana. 2004;56(1):157-61.

7. Von Krogh G, Lacey CJ, Gross G, Barrasso R, Schneider A. European course on HPV associated pathology: guidelines for primary care physicians for the diagnosis and management of anogenital warts. Sexually transmitted infections. 2000 Jun 1;76(3):162-8.

8. Balik E, Eren T, Bugra D; A surgical approach to anogenital Buschke Loewenstein tumours (giant condyloma acuminata). Acta Chir Belg, 2009; 109: 612-616.

9. Periskevas KI, Kyriakos E, Poulios EE, Stathopoulos V, Tzovaras AA, Briana DD; Surgical management of giant condyloma acuminatum (Buschke-Loewenstein tumor) of the perianal region. Dermatol Surg, 2007; 33(5):63844.

10. Sarzo G, Mistro A, Finco C, Frayle-Salamanca H, Marino F, Franzetti M. Extensive anal condylomatosis: prognosis in relation to viral and host factors. Colorectal Dis. 2010; $12(7$ Online):e128-34.

11. El Mejjad A, Dakir M, Tahiri M, Attar H, Cherkaoui A, Araki A, Aboutaieb R, Meziane F. Le condylome acuminé géant-Tumeur de Buschke Lowenstein (ā propos de 3 cas).

12. Qarro A, Ali AA, Choho A, Alkandry S, Borki K; Tumeur de Buschke-Loewenstein à localization anorectale (à propos de trois cas). Ann Chir. 2005; 130(2): 96-100.

13. Tytherleigh MG, Birtle AJ, Cohen CE, GlynneJones R, Livingstone J, Gilbert J; Combined surgery and chemo radiation as a treatment for the Buschke-Löwenstein tumour. Surgeon. 2006; 4(6): 378-383.

14. Gole G, Shekhar T, Gole S, Prabhala S. Successful treatment of Buschke-Löwenstein tumour by surgical excision alone. J Cutan Aesthet Surg. 2010;3:174.

15. Haque W, Kelly E, Dhingra S, Carpenter LS; Successful treatment of recurrent BuschkeLowenstein tumor by radiation therapy and chemotherapy. Int J Colorectal Dis. 2010; 25(4):539-540.

16. Armstrong N, Foley G, Wilson J, Finan P, SebagMontefiore D; Successful treatment of a large Buschke-Lowenstein tumour with chemoradiotherapy. Int J STD AIDS. 2009; 20(10):732-4

17. Bocquet $\mathrm{H}$, Bagot $\mathrm{M}$; Tumeurs bénignes d'origine virale. Encycl Med Chir Dermatologie. 1998; 9.

18. Machado I, Castillo A, Ochoa M, García R, Lamar Y; Condiloma gigante de Buschke y Lowenstein: A propósito de un caso. Dermatol. peru ene./abr. 2006; 16: 74-76.

19. Chu QD, Vezeridis MP, Libbey NP, Wanebo HJ; Giant condyloma Acuminatum (BuschkeLowenstein tumor) of the anorectal and perianal regions. Analysis of 42 cases. Dis Colon Rectum. 1994; 37(9): 950-957.

20. Papiu HS, Dumnici A, Olariu T, Onita M, Hornung E, Goldis D, Aiordachioae G, Vasca V. Perianal giant condyloma acuminatum (BuschkeLöwenstein tumor). Case report and review of the literature. Chirurgia (Bucur). 2011 Jul 1;106(4):535-9.

21. Hicheri J, Jaber K, Dhaoui MR, Youssef S, Bouziani A, Doss N; Giant condyloma (BuschkeLöwenstein tumor). A case report. Acta Dermatovenerol Alp Panonica Adriat, 2006; 15(4): 181-183.

22. Gutiérrez N, Enríquez B, Villar AL. Condiloma gigante y embarazo. Rev Cubana Obstet Ginecol. 2003; 29(3): 0-0. 
23. Bertram P, Treutner KH, Rubben A, Hauptmann S, Schumpelick V; Invasive squamous-cell carcinoma in a giant anorectal condiloma (Buschke Lowenstein tumor). Langenbecks Arch Chir. 1995; 380: 115-118.

24. Moreira M, Pérez A, Colomé M; Condiloma gigante inguinal (tumor de Buschke Lowenstein) con aspecto clínico de carcinoma escamoso. Rev Cubana Med Trop Abr. 2000; 52(1): 70-72.

25. Peng HH, Wang TH, Huang KG, Ng KK, Hsueh S, Chen MY; Combined ultrasound and magnetic resonance imaging findings on cervical verrucous carcinoma with endometrial invasion: a case report. JReprod Med. 2007; 52(5): 441-444.

26. Reichenbach I, Koebell A, Foliguet B, Hatier M, Mascotti J, Landes P; Tumeur de Buschke et Lowenstein à propos d'un cas feminin. J Gynecol Obstet Biol Reprod. 1995; 24: 491- 495.

27. Noorwood $\mathrm{CH}$, Mather MK; Giant Condylomata Acuminata of Buschke and Lowenstein. 2013.

28. Bogomoletz WV, Potet F, Molas G; Condylomata acuminate, giant condyloma acuminatum (Buschke-Löwenstein tumor) and verrucous squamous cell carcinoma of the perianal and anorectal region: a continuous precancerous spectrum? Histopathology. 1985; 9: 155-169.
29. Chu QD, Vezeridis MP, Libbey NP, Wanebo HJ. Giant condyloma acuminatum (BuschkeLöwenstein tumor) of the anorectal and perianal regions: analysis of 42 cases. Dis Colon Rectum. 1994; 37: 950-957.

30. Rubben A, Beaudenon S, Favre M. Rearrangements of the upstream regulatory region of human papilloma virus type 6 can be found in both Buschke-Löwenstein tumours and in condylomata acuminata. J Gen Virol. 1992; 73: 3147-3153.

31. Castren K, Vahakangas K, Heikkinen E, Ranki A. Absence of p53 mutations in benign and premalignant male genital lesions with over expressed p53 protein. Int J Cancer. 1998; 77: 674-678.

32. Renzi A, Brusciano L, Giordano P, Rossetti G, Izzo D, Del Genio A; Busche-Löwenstein tumor. Successful treatment by surgical electrocautery excision alone: a case report. Chir Ital. 2004; 56: 297-300.

33. Chao MWT, Gibbs P. Squamous cell carcinoma arising in a giant condyloma acuminatum (Buschke-Löwenstein tumor). Asian JSurg. 2005; 28: 238-240. 